\title{
The Development of Taxation Learning Media Based on Articulate Storyline
}

\author{
Dedy Husrizal Syah ${ }^{1, *}$, Eko Wahyu Nugrahadi ${ }^{1}$, Taufik Hidayat ${ }^{1}$, Azizul Kholis ${ }^{1}$ \\ ${ }^{1}$ State University of Medan \\ *Corresponding author.Email: dedy@unimed.in
}

\begin{abstract}
This study aims to (1) develop interactive learning media based on articulate storylines in tax courses; (2) test the feasibility of learning media developed based on the validation/assessment of expert teams and students; and (3) test the effect of the use of learning media developed on academic performance. This study is a type of research and development by following the ADDIE development model (Analysis, Design, Development, Implementation and Evaluation). Still, here the model used only until the fourth stage (4) that is implementation. Validation was carried out by the Lecturer Supervisory Team and the Media Expert Lecturer Team. It was tested on 35 students of the Digital Business study program, Faculty of Economics, State University of Medan. The study was conducted from June to September 2020. The data collection technique was carried out using a questionnaire. Media validation was carried out by the Media Expert Lecturer Team and was tested on 35 students of the Digital Business study program at the State University of Medan in 2019. Broadly speaking, the results of the validation of the media aspect were classified as a Very Appropriate category, with the percentage $94.14 \%$ and the results of field trial assessments were also classified as a very feasible category with the percentage $92.87 \%$.
\end{abstract}

Keywords: Taxation, Articulate Storyline, Learning Media

\section{INTRODUCTION}

Education is an important investment and has a strategic role in the creation of quality human resources [1]. The higher the achievement of the quality of human resources will also correlate with good education [2]. Deciding to continue to innovate in learning is an option that must be chosen by educators [3]. Mastery of science and technology is an indicator of success in achieving the quality of education and improving human resources [4]; [5].

The tax course is an essential field for accounting students to master. However, for most students, taxation is still considered difficult to study [6];[7]. Student difficulties generally come from the assumption that taxation contains formulas and rules that are difficult to understand [8]. The difficulty in understanding taxation courses is generally caused by a lack of innovative teaching materials used by educators in the learning process [9];[10]. It is in line with the results of observations in several tax classes in the past semesters that almost all students have computers and laptops. The existence of adequate facilities has not been able to support the implementation of classroom and independent learning. Lecturers as teachers use teaching materials and conventional media in delivering subject matter.

Based on these observations, here students need some interesting, innovative and easy-to-use teaching materials to convey messages well as appropriate visualizations to provide understanding to students [11]. [12] defines teaching materials as any form of material used to help educators or instructors in carrying out the learning process in the classroom. So teaching materials are all forms of material that can support learning. One form of teaching material includes modules [13]. The current module is divided into two categories, namely print modules and digital modules. Digital modules have the advantage of being able to display some material using interactive learning media [14]; [15].

One type of learning media that can be applied in the classroom is interactive learning media. The application of interactive learning media (IT-based) is the primary demand in the current era of globalization [16]. [17] states that technology applied to learn should be 
integrated with learning models to achieve learning objectives. Interactive learning media makes it easier for teachers to teach abstract material [18]. Some interactive learning media are considered capable of explaining phenomena that occur in nature and presenting them in the classroom [19].

An articulate Storyline is a software that can be used as a media for presentation and conveying information. Articulate Storyline is suitable for use as a learning media Articulate Storyline is a software that can be used as a medium for presentation and conveying information. Articulate Storyline is suitable for use as a learning medium that can compete with adobe flash media [20]. The difference from Adobe Flash, which is the media most often used as interactive learning media today, is that Articulate Storyline does not require programming languages or scripts in the manufacturing process. All animation commands can be done with the "trigger" menu so that they can make it easier for teachers to create interactive learning media. The Articulate Storyline program has several advantages, namely simple smart brainware. The program also makes it easy for users to publish online and offline so that it can be formatted on $\mathrm{CD}$, word processing, personal pages and LMS [21].

The results of interviews with students who took taxation practicum stated that taxation material was challenging to understand, there were no references in the form of modules and too brief explanations because of the short time. As a result of the lack of teaching materials, it can hinder the achievement of learning objectives so that the development of teaching materials needs to be done [22]. In addition, it is necessary to have an appropriate learning method and model to adjust the time and material available.

Based on this background, efforts are needed to increase the role of learning media [23] in teaching the concept of taxation, especially for explaining concepts that require practicum through interactive media. Based on the problems that have been described, the researchers felt the need to develop an interactive digital learning media for taxation courses. Learning using interactive media Articulate Storyline is expected to increase the effectiveness of learning in lectures. Robertson and East revealed in their research that only $32 \%$ of students got good scores. However, after the learning media using the Articulate Storyline was implemented, there were 95\% who met the grades according to the set curriculum [24].

\section{METHOD}

This study uses a research development method (Research and Development) that is usually used to produce a certain product and test the product's feasibility [25]. This research produces a product that can be used in the learning process in the form of an interactive application based on the articulate Storyline. Research on the development of a product for learning media is carried out to determine the feasibility of the media in the learning process. Therefore, it is necessary to have a research design that has stages so that this research can run well. The stages of research carried out refer to the ADDIE development model, which includes Analysis, Design, Development, Implementation and Evaluation [26].

The stages of this research design are carried out through the analysis stage (such as; curriculum and material analysis, media analysis and user target characteristics), the design stage (such as; designing the material items to be presented, compiling the material texts, and arranging the flow of material delivery in the form of a flowchart), the development stage (such as; The making of media using the articulate storyline software, assessment by validation experts, revisions), the implementation stage (such as; limited trial), and the evaluation stage (such as; media revision from the results of suggestions and comments after a limited trial).

This research on the development of interactive learning media based on the Articulate Storyline in the Taxation course was conducted at the Digital Business Study Program, Faculty of Economics, State University of Medan. This research was conducted over a period of time, from June to September 2020.

The research subjects consisted of media validation and trial subjects. The subjects of media validation included two media expert lecturers of the educational technology department. Product trials are field trials. The field trial subjects are students who are taking the Taxation course in the current semester as many as 35 students. The design of this application product is done using the Articulate Storyline application.

The collecting data in this study is using a questionnaire/media validation and testing instruments. The media validation instrument contains a media validation sheet for instructional media experts while the test instrument is a sheet for assessing the quality of learning material by students (used in field trials). The validation and material assessment instruments were adapted from Walker \& Hess [27].

\section{RESULTS AND DISCUSSION}

The steps that have been taken in application development include (1) the identification stage of student problems starting from their character and abilities as well as their motivation in lectures, (2) the product design stage starting from designing the subject matter in taxation courses, including a) Taxes Income, b) $\mathrm{PPh} 22$, c) Income Tax 23, d) Income Tax 25, and e) Income Tax 26. At this stage, a flowchart design is also carried out which explains in detail the components and layout of the instructional media with the help of a paid application, namely Articulate Storyline, (3) then 
proceed with the application testing phase by the lecturer as a media expert by using a validated instrument that measures in terms of interface and multimedia as well as modification and revision of the product based on the recommendations and suggestions of the media experts. (4) after going through the validation stage by media experts, the next stage is testing the feasibility of direct applications to \pm 35 students of the Digital Business study program at the State University of Medan, both testing the feasibility of concepts, materials and potential.

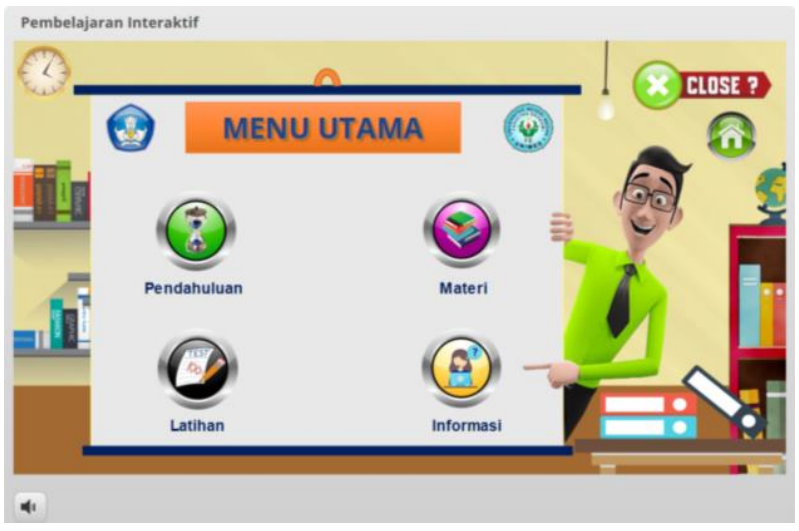

Figure 1. Main Menu Display

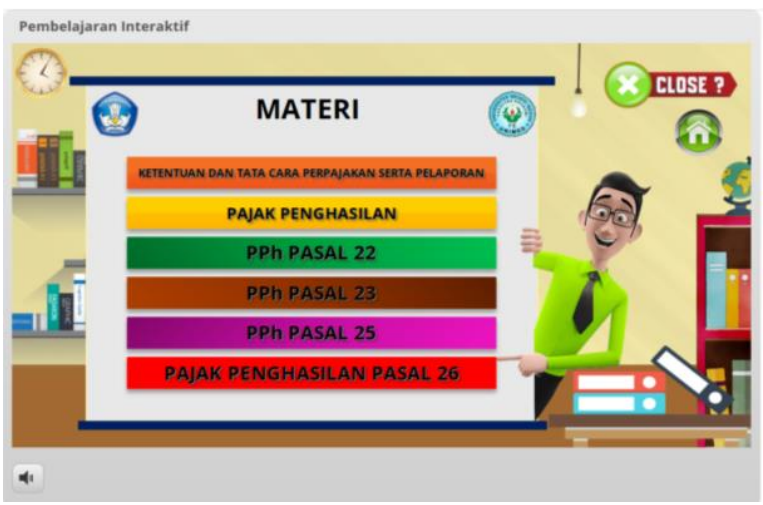

Figure 2. Material Menu Display

Product validation was carried out by two media experts' team, they are the lecturers who teach the Taxation Subject. Product validation was carried out using media assessment instruments that have been validated by the research instrument validator in terms of content and construct. The assessment by media experts was assessed based on two aspects, namely the interface aspect with percentage $94.29 \%$ and the multimedia aspect with percentage $94 \%$, in other words, the validation of the media expert team produced average value $94.14 \%$ so that it could be categorized as very feasible. The following pictures are four diagrams of the assessment results from media experts.

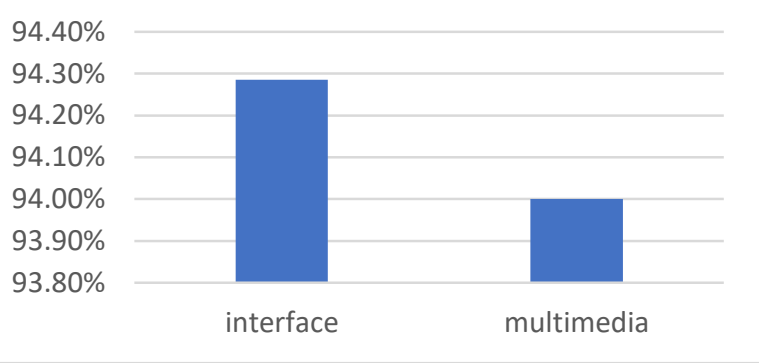

Figure 3 Media Expert Assessment Diagram

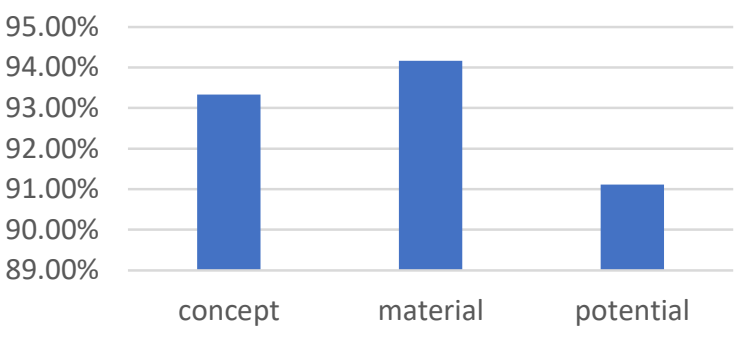

Figure 4. Field Trial Assessment Diagram

The results of the field trial assessment to students of the developed learning media products were assessed at the validation stage consisting of aspects of the truth of the concept with percentage $93.33 \%$, preparation of the material with percentage $94.17 \%$ and aspects of the potential implementation with percentage $91.11 \%$. The average results of this Trial assessment are stated at $92.87 \%$ so that it can also be categorized as very feasible

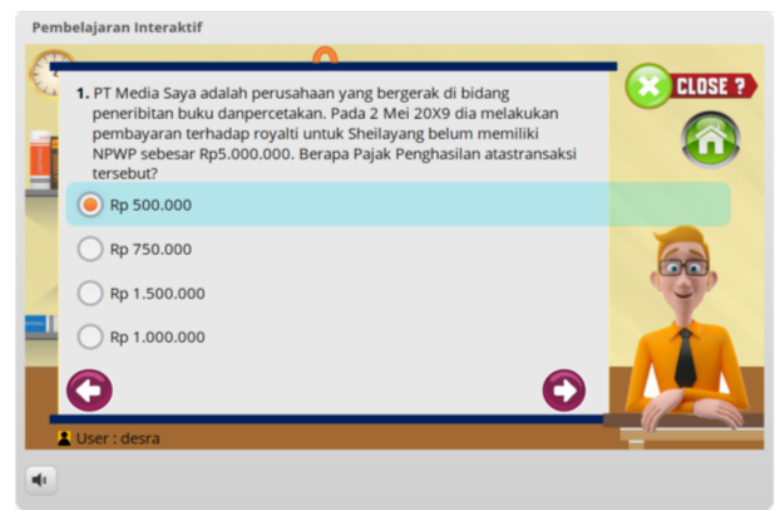

Figure 5. Exercise Menu Display 


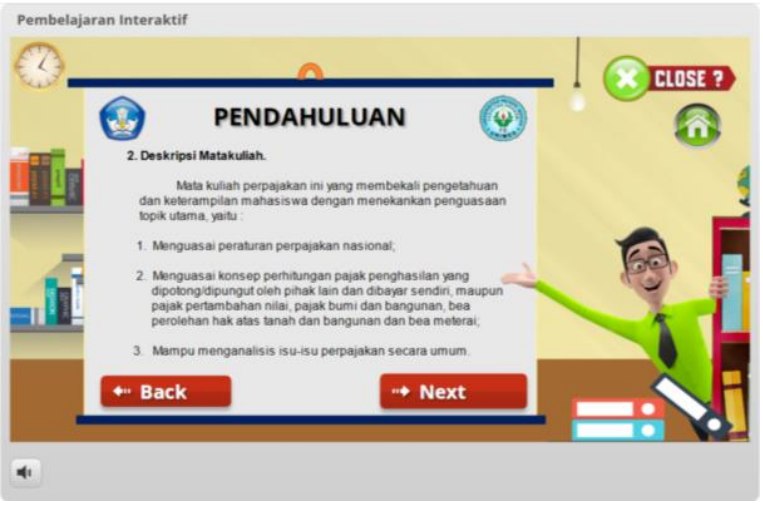

Figure 6. Introduction Menu Display

Based on the output table 4.5 , the sig value is obtained. (2-tailed) of $0.000<0.05$, it can be concluded that there is a difference in the average student test results between video conference-based learning and non-video conference learning.

\section{CONCLUSIONS}

The development of learning media in the Taxation course for the Digital Business Study Program at Medan State University has been successfully developed using the Articulate Storyline application. Based on the assessment by media experts' team, the percentage score was $94.14 \%$, so it was included in the very feasible category.

Likewise, the acquisition of the results of student field trial assessments resulted in a percentage of $92.87 \%$ and was also categorized as very feasible, therefore, the development of Taxation learning media is worthy and feasible used as a learning media and independent learning resource.

\section{ACKNOWLEDGMENTS}

This research was funded by the State University of Medan from the Unimed PNBP Basic Research program in 2020 .

\section{REFERENCES}

[1] Jenilan, J. FILSAFAT PENDIDIKAN. ELAFKAR : Jurnal Pemikiran Keislaman Dan Tafsir Hadis. 2018.

https://doi.org/10.29300/jpkth.v7i1.1588.

[2] Krismiyati, K. Pengembangan Sumber Daya Manusia dalam Meningkatkan Kualitas Pendidikan di SD Negeri Inpres Angkasa Biak. Jurnal Office. 2017. https://doi.org/10.26858/jo.v3i1.3459.

[3] Asyhari, A., \& Diani, R., Pembelajaran fisika berbasis web enhanced course: mengembangkan web-logs pembelajaran fisika dasar I. Jurnal Inovasi
Teknologi

Pendidikan.

2017.

https://doi.org/10.21831/jitp.v4i1.13435.

[4] Byun, J., Sung, T. E., \& Park, H. W. Technological innovation strategy: how do technology life cycles change by technological area. Technology Analysis and Strategic Management. 2018. https://doi.org/10.1080/09537325.2017.1297397

[5] Heeks, R., \& Stanforth, C. Technological change in developing countries: Opening the black box of process using actor-network theory. Development Studies Research. 2015. https://doi.org/10.1080/21665095.2015.1026610

[6] Agustina, \& Yanti, D. M. (2015). Analisis FaktorFaktor yang Mempengaruhi Tingkat Pemahaman Akuntansi Mahasiswa Jurusan Akuntansi STIE Mikroskil Medan. Jurnal Wira Ekonomi Mikroskil, 2015.

[7] Kusumaningtyas, M. T., \& Rusydi, M. K. Pengaruh Persepsi Dan Motivasi Terhadap Minat Mahasiswa Jurusan Akuntasi Fakultas Ekonomi Dan Bisnis Universitas Brawijaya Berkarir Di Bidang Perpajakan. Jurnal Ilmiah Mahasiswa FEB, 2012.

[8] Lubis, A., Ginting, P., \& Batubara, A., Pengaruh Kualitas Pelayanan Terhadap Kepuasan Dan Word of Mouth Mahasiswa Program Studi Diploma III Administrasi Perpajakan Fisip Usu. Jurnal Ilmiah Manajemen Dan Bisnis UMSU. 2014.

[9] Hamidulloh Ibda. Penguatan Literasi Perpajakan Melalui Strategi“GEBUK" (Gerakan Membuat Kartu) NPWP Pada Mahasiswa. Jurnal Ekonomi Pendidikan Dan Kewirausahaan. 2019. https://doi.org/10.1017/CBO9781107415324.004

[10] Horri, M., \& Handayani, A. E. Pengaruh kecerdasan emosional terhadap tingkat pemahaman akuntansi pada mahasiswa akuntansi di universitas dr.soetomo. Jurnal Analisa Akuntansi Dan Perpajakan. 2019. https://doi.org/10.25139/jaap.v2i2.1396

[11] Erawanto, U., \& Santoso, E., Pengembangan Modul Pembelajaran Berbasis Masalah Untuk Membantu Meningkatkan Berfikir Kreatif Mahasiswa. JINoP (Jurnal Inovasi Pembelajaran). 2016. https://doi.org/10.22219/jinop.v2i2.2629

[12] Al Azka, H. H., Setyawati, R. D., \& Albab, I. U. Pengembangan Modul Pembelajaran. Imajiner: Jurnal Matematika Dan Pendidikan Matematika. 2019. https://doi.org/10.26877/imajiner.v1i5.4473

[13] Hernawan, A. H., \& Andriyani, D., Hakikat Kurikulum dan Pembelajaran. Modul Pembelajaran. 2014. 
[14] Febrianti, K. V., Bakri, F., \& Nasbey, H. Pengembangan modul digital fisika berbasis discovery learning pada pokok bahasan kinematika gerak lurus. WaPFi (Wahana Pendidikan Fisika). 2017. https://doi.org/10.17509/wapfi.v2i2.8273.

[15] Sugianto, D., Abdullah, A. G., Elvyanti, S., \& Muladi, Y. Modul Virtual: Multimedia Flipbook Dasar Teknik Digital. Innovation of Vocational Technology Education. 2017. https://doi.org/10.17509/invotec.v9i2.4860.

[16] Sanaky, H. A. H. Media Pembelajaran InteraktifInovatif. In Kaukaba Dipantara. 2013

[17] Tarigan, D., \& Siagian, S., Pengembangan Media Pembelajaran Interaktif Pada Pembelajaran Ekonomi. JURNAL TEKNOLOGI INFORMASI \& KOMUNIKASI DALAM PENDIDIKAN. 2015. https://doi.org/10.24114/jtikp.v2i2.3295

[18] Istiqlal, M. pengembangan multimedia interaktif dalam pembelajaran matematika. JIPMat. 2017. https://doi.org/10.26877/jipmat.v2i1.1480

[19] Mustika, Rampengan, C. G., Sanjaya, R., \& Sofyan. Implementasi Augmented Reality Sebagai Media Pembelajaran Interaktif. Citec Journal. 2015.

[20] Pratama, R. A., Media Pembelajaran Berbasis Articulate Storyline 2 Pada Materi Menggambar Grafik Fungsi Di Smp Patra Dharma 2 Balikpapan. JURNAL DIMENSI. 2019. https://doi.org/10.33373/dms.v7i1.1631

[21] Koerner, M. M. Courage as identity work: Accounts of workplace courage. Academy of Management Journal. 2014. https://doi.org/10.5465/amj.2010.0641

[22] Purnomo, D., Pengembangan Bahan Ajar Matematika Sebagai Sarana Pengembangan Kreativitas Berpikir. Aksioma: Jurnal Matematika Dan Pendidikan Matematika UPGRIS Semarang, 2011.

[23] Mahnun, N., Media Pembelajaran (Kajian terhadap Langkah-langkah Pemilihan Media dan Implementasinya dalam Pembelajaran). An-Nida'. 2012.

[24] Novak, E., Johnson, T. E., Tenenbaum, G., \& Shute, V. J., Effects of an instructional gaming characteristic on learning effectiveness, efficiency, and engagement: using a storyline for teaching basic statistical skills. Interactive Learning Environments. 2016 https://doi.org/10.1080/10494820.2014.881393

[25] Sugiyono. Open Library - Metode Penelitian Kuantitatif, Kualitatif dan R\&D. Alfabeta, 2016.
[26] Hishamudin, F. Model ADDIE. Universiti Teknologi Malaysia. 2016.

[27] Syah, D. H., Ane, L., Hidayat, T., \& Rahman, H. The Development of Financial Statement Analysis Learning Media to Enhance Student Analysis Abilities. Assets: Jurnal Akuntansi Dan Pendidikan. 2020. https://doi.org/10.25273/jap.v9i1.5348 